\title{
Kinerja Keuangan Usaha Mikro Kecil dan Menengah di Kabupaten Cirebon Sebelum dan Sesudah Mendapatkan Pembiayaan Syariah
}

\author{
Siti Jubaedah \\ Rina Destiana \\ destirin@gmail.com \\ Fakultas Ekonomi Universitas Swadaya Gunung Jati, Cirebon
}

\begin{abstract}
ABSTRAK
Usaha Mikro Kecil dan Menengah merupakan tulang punggung ekonomi bangsa yang telah terbukti tangguh menghadapi krisis moneter tahun 1998. Peningkatan peran UMKM dalam perekonomian nasional merupakan tanggung jawab pemerintah baik pusat maupun daerah, dunia usaha, lembaga keuangan dan masyarakat. Untuk meningkatkan peran UMKM, satu hal yang perlu mendapat perhatian adalah kemudahan UMKM untuk mengakses sumber daya finansial dari perbankan. Penelitian ini bertujuan untuk menganalisis kinerja keuangan UMKM di Kabupaten Cirebon yang diproksikan dengan jumlah aset, omset penjualan dan laba bersih sebelum dan sesudah mendapatkan pembiayaan syariah. Penelitian ini merupakan penelitian lanjutan dari penelitian yang pernah dilakukan. Data sekunder dari Bank Syariah Mandiri Cabang Cirebon dianalisis menggunakan uji beda sampel berpasangan (paired sample $t$ test). Hasil penelitian menunjukkan bahwa terdapat perkembangan jumlah aset, omset penjualan dan laba bersih UMKM di Kabupaten Cirebon setelah mendapatkan pembiayaan dari Bank Syariah Mandiri Cabang Cirebon.

Kata kunci : Aset, laba bersih, omset penjualan, pembiayaan syariah, UMKM
\end{abstract}

\section{PENDAHULUAN}

Usaha Mikro Kecil dan Menengah (UMKM) merupakan tulang punggung ekonomi bangsa yang telah terbukti tangguh menghadapi krisis moneter tahun 1998. Keberadaannya hingga kini menopang perekonomian Indonesia dan berkontribusi besar dalam hal penerimaan devisa negara karena produk-produk UMKM mampu bersaing bukan saja di tingkat regional tetapi juga internasional. Peranan UMKM dalam menciptakan dan memperluas lapangan pekerjaan di
Indonesia sehingga meningkatkan pendapatan masyarakat, meningkatkan laju pertumbuhan ekonomi dan berkontribusi bagi peningkatan Produk Domestik Bruto (PDB), semuanya itu bisa dioptimalkan jika sektor ini terus mendapat perhatian dan dukungan dari para pemangku kebijakan di negeri ini.

Karaktiristik UMKM di Indonesia, berdasarkan penelitian yang dilakukan oleh AKATIGA, The Center for Micro and Small Enterprise Dynamic (CEMSED) dan The Center for Economic and Social Studies 
(CESS) pada tahun 2000, yaitu mempunyai daya tahan untuk hidup dan mempunyai kemampuan untuk meningkatkan kinerja keuangannya selama krisis ekonomi. Hal ini disebabkan oleh fleksibilitas UMKM dalam melakukan penyesuaian proses produksinya, mampu berkembang dengan modal sendiri, mampu mengembalikan pinjaman dengan bunga tinggi dan tidak terlalu terlibat dalam hal birokrasi (Rahmana, 2008).

Peningkatan peran UMKM

dalam perekonomian nasional merupakan tanggung jawab Pemerintah, Pemerintah Daerah, dunia usaha, lembaga keuangan dan masyarakat secara menyeluruh dan berkelanjutan tentunya. Dengan meningkatkan peran UMKM di Indonesia diharapkan dapat berkontribusi positif yang signifikan dalam upaya-upaya mengatasi berbagai permasalahan di bidang ekonomi dan sosial, seperti masalah pengangguran dan kemiskinan, rendahnya tingkat pendidikan, distribusi pembangunan dan pendapatan masyarakat yang belum merata dan lain sebagainya.

Satu hal yang perlu mendapatkan perhatian untuk lebih memberdayakan UMKM adalah meningkatan akses UMKM kepada sumber daya finansial. Keterbatasan sumber daya finansial atau permodalan seringkali menjadi penghambat sektor UMKM untuk mengembangkan usaha dan memperluas jaringan mereka. Dalam hal ini tentu saja UMKM membutuhkan dukungan dari lembaga keuangan seperti perbankan. Meskipun pemerintah melalui Bank Indonesia telah membuat kebijakan yang mengharuskan bank-bank umum untuk menyalurkan pembiayaannya kepada sektor UMKM, namun pada kenyataannya di lapangan ternyata tidak semudah yang dibayangkan. Aturan- aturan dan prosedur-prosedur yang dibuat oleh pihak bank adakalanya menyulitkan pelaku UMKM untuk mendapatkan pembiayaan dari bank, terlebih lagi jika pihak bank mengharuskan adanya aset sebagai jaminan. Pada akhirnya pelaku UMKM hanya mengandalkan modal sendiri untuk membangun dan mengembangkan usahanya. Tidak sedikit dari mereka yang sulit berkembang dan maju karena kendala permodalan hingga banyak diantara mereka yang tidak bisa melanjutkan usaha, terpaksa tutup atau gulung tikar.

Kabupaten Cirebon merupakan salah satu penyumbang UMKM di Jawa Barat. Kabupaten Cirebon dikenal sebagai sentra industri kerajinan rakyat, karena memiliki sentra-sentra industri yang berbasis kerakyatan. Menurut dinas perindustrian dan perdagangan tahun 2012, Kabupaten Cirebon memiliki sembilan jenis komoditi unggulan yang dijadikan sentra kerajinan industri, diantaranya industri rotan yang berkembang di Kecamatan Plumbon, Weru, Depok dan Palimanan, industri batik yang tersebar di Kecamatan Plered dan Desa Kalibaru Kecamatan Kedawung, indutri batu alam di Palimanan dan Kecamatan Dukupuntang hasil produksi berupa aksesories dinding, lantai maupun taman, industri makanan ringan, yang tersebar di Kecamatan Kedawung, Plered, Tengahtani dan Plumbon, dimana semua kegiatan usaha tersebut masuk dalam kategori sektor usaha kecil menengah, bahkan ada juga skala mikro seperti pedagang makanan dan minuman yang biasanya mangkal di sekitar lokasi produksi dan memiliki ketergantungan dari aktivitas kegiatan usaha tersebut (Jubaedah dan Destiana, 2015).

Kinerja keuangan pada dasarnya digunakan sebagai alat untuk mengukur 
kesehatan perusahaan. Kinerja keuangan perusahaan digunakan sebagai media pengukuran subjektif yang menggambarkan efektivitas penggunaan aset oleh sebuah perusahaan dalam menjalankan bisnis utamanya dan meningkatkan pendapatan. Memba et al. (2012) menyatakan bahwa indikator kinerja keuangan UKM adalah penjualan per tahun, laba per tahun, aset bersih dan jumlah pekerja. Widodo et al. (2003) menyatakan ukuran dalam menentukan kinerja usaha mikro menggunakan indikator-indikator kinerja yaitu nilai penjualan, keuntungan, nilai aset usaha, nilai aset keluarga, kredit, biaya hidup keluarga, dan tabungan keluarga. Mengacu pada Memba et al. (2012) dan Widodo et al. (2003), penelitian ini menggunakan aset, omset penjualan dan laba bersih sebagai indikator pengukuran kinerja keuangan UMKM. Aset adalah sumber daya yang dikuasai entitas sebagai akibat dari peristiwa masa lalu dan dari mana manfaat ekonomi dimasa depan diharapkan akan diperoleh perusahaan (IAI, 2009). Omset penjualan adalah akumulasi dari kegiatan penjualan suatu produk barang barang dan jasa yang dihitung secara keseluruhan selama kurun waktu tertentu secara terus menerus atau dalam satu proses akuntansi (Swastha, 2001). Laba adalah semua unsur pendapatan dan beban yang diakui dalam suatu periode (IAI, 2007). Laba bersih merupakan laba yang diperoleh dari seluruh pendapatan dikurangi dengan seluruh biaya, sesudah dikurangi pajak perseroan.

Berdasarkan uraian di atas, maka penelitian ini menganalisis apakah terdapat perbedaan kinerja keuangan UMKM antara sebelum dan sesudah mendapatkan pembiayaan dari bank syariah. Adapun kinerja keuangan keuangan UMKM dilihat dari segi perkembangan aset, omset penjualan dan laba bersih selama kurun waktu tertentu.

\section{KAJIAN PUSTAKA, KERANGKA PEMIKIRAN DAN PERUMUSAN HIPOTESIS}

\section{Bank Syariah}

Bank merupakan salah satu lembaga keuangan yang mempunyai peranan penting di dalam perekonomian suatu negara sebagai badan usaha yang menghimpun dana dari masyarakat dalam bentuk simpanan dan menyalurkannya kepada masyarakat dalam bentuk kredit atau bentuk-bentuk lainnya dalam rangka meningkatkan taraf hidup rakyat banyak.

Perbankan syariah menurut UU RI No. 21 tahun 2008 pasal 1 ayat 1 adalah segala sesuatu yang menyangkut tentang Bank Syariah atau Unit Usaha Syariah, mencakup kelembagaan, kegiatan usaha, serta cara dan proses dalam melaksanakan kegiatan usahanya. Bank syariah yaitu bank yang dalam aktivitasnya, baik penghimpunan dana maupun dalam rangka penyaluran dananya memberikan dan mengenakan imbalan atas dasar prinsip syariah yaitu jual beli dan bagi hasil (Peraturan Bank Indonesia No. 9/7/PBI/2007). Hal mendasar yang membedakan bank konvensional dan bank syariah adalah terletak pada pengembalian dan pembagian keuntungan yang diberikan oleh nasabah kepada bank dan atau yang diberikan oleh bank kepada nasabah.

Bank syariah tidak menggunakan bunga sebagai alat untuk memperoleh pendapatan maupun membebankan bunga atas penggunaan dana dan pinjaman karena bunga merupakan riba yang diharamkan. Kegiatan operasional yang dilakukan oleh bank syariah menggunakan prinsip bagi hasil (profit and loss sharing).

Lahirnya bank syariah yang beroperasi berdasarkan sistem bagi hasil sebagai alternatif pengganti bunga pada bank-bank konvensional yang merupakan peluang bagi umat Islam untuk memanfaatkan jasa bank konvensional. Hal ini merupakan 
peluang bagi umat Islam untuk memanfaatkan jasa bank seoptimal mungkin. Dengan demikian umat Islam akan berhubungan dengan perbankan dengan tenang tanpa keraguan yang didasari oleh motivasi keagamaan yang kuat di dalam memobilisasi dana masyarakat untuk pembiayaan pembangunan ekonomi umat.

\section{Usaha Mikro Kecil dan Menengah (UMKM)}

Di Indonesia, definisi UMKM diatur dalam Undang-Undang Republik Indonesia Nomor 20 Tahun 2008 tentang UMKM. Dalam Bab I (Ketentuan Umum), Pasal 1 dari UU tersebut, dinyatakan bahwa usaha mikro adalah usaha produktif milik orang perorangan dan/atau badan usaha perorangan yang memenuhi kriteria usaha mikro sebagaimana diatur dalam UU tersebut.Usaha kecil adalah usaha ekonomi produktif yang berdiri sendiri, yang dilakukan oleh orang perorangan atau badan usaha yang bukan merupakan anak perusahaan atau bukan cabang perusahaan yang dimiliki, dikuasai, atau menjadi bagian, baik langsung maupun tidak langsung, dari usaha menengah atau usaha besar yang memenuhi kriteria usaha kecil sebagaimana dimaksud dalam UU tersebut.

Sedangkan usaha menengah adalah usaha ekonomi produktif yang berdiri sendiri, yang dilakukan oleh orang perorangan atau badan usaha yang bukan merupakan anak perusahaan atau bukan cabang perusahaan yang dimiliki, dikuasai, atau menjadi bagian, baik langsung maupun tidak langsung, dari usaha mikro, usaha kecil, atau usaha besar yang memenuhi kriteria usaha menengah sebagaimana dimaksud dalam UU tersebut.

\section{Kinerja Keuangan UMKM}

Kinerja keuangan adalah sesuatu yang dicapai atau prestasi yang diperlihatkan (Kamus Besar Bahasa Indonesia, 2001). Menurut Trisnantoro dan Agastya (1996), kinerja keuangan merupakan proses yang dilakukan dan hasil yang dicapai oleh suatu organisasi dalam memberikan jasa atau produk kepada pelanggan.

Dalam penelitian ini, kinerja keuangan UMKM diukur dari jumlah aset, omset atau volume penjualan dan laba usaha yang diperoleh UMKM selama kurun waktu tertentu. Aset merupakan kekayaan (sumber daya) yang dimiliki oleh entitas bisnis yang bisa diukur secara jelas menggunakan satuan uang serta sistem pengurutannya berdasar pada seberapa cepat perkembangannya dikonversi menjadi satuan uang kas. Bermanfaat secara langsung ataupun tak langsung, sifatnya produktif dan masuk dalam bagian operasi perusahaan dan memiliki kemampuan dalam mengurangi pengeluaran kas. Memiliki potensi manfaat di masa yang akan datang, potensi manfaat tersebut bisa dalam bentuk hal-hal produktif yang bisa menghasilkann kas ataupun setara kas. Manfaat lain dari aset adalah sebagai penghasil barang dan jasa, dapat ditukar dengan aktiva lain, melunasi kewajiban (hutang). Omset penjualan identik dengan volume penjualan. Omset penjualan akan meningkat jika diiringi dengan kegiatan penjualan yang efektif. Kata omset berarti jumlah, sedangkan penjualan berarti kegiatan menjual barang yang bertujuan mencari laba atau pendapatan. Jamal dkk (2013) menerangkan bahwa omset penjualan merupakan keseluruhan jumlah penjualan barang atau jasa dalam kurun waktu tertentu, yang dihitung berdasarkan jumlah uang yang diperoleh. Laba bersih merupakan 
kelebihan total pendapatan dibandingkan total bebannya. Disebut juga pendapatan bersih atau net earnings.

\section{Kerangka Pemikiran dan Hipotesis}

\begin{tabular}{|c|c|}
\hline $\begin{array}{l}\text { Jumlah } \\
\text { Aset }\end{array}$ & $\begin{array}{l}\text { Kinerja Keuangan } \\
\text { UMKM Sebelum }\end{array}$ \\
\hline $\begin{array}{c}\text { Omset } \\
\text { Peniulalan }\end{array}$ & $\begin{array}{l}\text { Pembiayaan } \\
\text { Syariah (X1) }\end{array}$ \\
\hline & $\begin{array}{l}\text { Kinerja Keuangan } \\
\text { UMKM Sesudah }\end{array}$ \\
\hline $\begin{array}{l}\text { Laba } \\
\text { Bersih }\end{array}$ & $\begin{array}{l}\text { Pembiayaan } \\
\text { Syariah (X2) }\end{array}$ \\
\hline
\end{tabular}

$\mathrm{H}_{\mathrm{a} 1}$ : terdapat perkembangan jumlah aset UMKM sesudah mendapatkan pembiayaan syariah.

$\mathrm{H}_{\mathrm{a} 2}$ : terdapat perkembangan omset penjualan UMKM sesudah mendapatkan pembiayaan syariah.

$\mathrm{H}_{\mathrm{a} 3}$ : terdapat perkembangan laba bersih UMKM sesudah mendapatkan pembiayaan syariah.

\section{METODE PENELITIAN Variabel Penelitian}

Variabel penelitian yang digunakan dalam penelitian ini adalah kinerja keuangan keuangan UMKM sebelum pembiayaan syariah (X1) dan kinerja keuangan UMKM sesudah pembiayaan syariah (X2).

Variabel kinerja keuangan yang digunakan dalam penelitian ini diproksikan oleh jumlah aset, omset penjualan dan laba bersih. Aset diukur dengan total aset yang dimiliki oleh UMKM sebelum dan sesudah mendapatkan pembiayaan dari bank syariah. Omset penjualan diukur dengan keseluruhan jumlah penjualan barang atau jasa selama kurun waktu tertentu, yang dihitung berdasarkan jumlah uang yang diperoleh, sebelum dan sesudah mendapatkan pembiayaan syariah. Laba bersih adalah laba operasi dikurangi pajak, biaya bunga, biaya riset, dan pengembangan. Dalam penelitian ini, laba bersih diukur dengan pendapatan bersih yang diperoleh UMKM sebelum dan sesudah mendapatkan pembiayaan syariah.

\section{Populasi dan Sampel}

Populasi dalam penelitian ini adalah UMKM yang memperoleh pembiayaan dari Bank Syariah Mandiri (BSM) cabang Cirebon. Metode sampel yang digunakan dalam penelitian ini adalah Random Sampling, dimana sampel diambil secara acak (Indriantoro, 2009).

\section{Teknik Pengumpulan Data}

Jenis data yang digunakan dalam penelitian ini adalah data sekunder. Data sekunder menggunakan data yang telah dihimpun oleh Bank Syariah Mandiri Cabang Cirebon. Data tersebut berupa nasabah UMKM yang mendapatkan pembiayaan syariah beserta data aset, omset penjualan dan laba sebelum dan sesudah mendapatkan pembiayaan.

Metode pengumpulan data diperoleh dengan cara dokumentasi. Dalam hal ini, data-data yang diperoleh dari Bank Syariah Mandiri Cabang Cirebon dan dikumpulkan kemudian dilakukan pencatatan untuk dianalisis lebih lanjut.

\section{Teknik Analisis Data}

Analisis statistik diperlukan untuk menguji hipotesis penelitian sehingga menghasilkan kesimpulan diterima atau ditolaknya hipotesis penelitian. Analisis 
data penelitian menggunakan software SPSS versi 18.0 for Windows untuk menguji apakah ada perbedaan rata-rata dua sampel yang berpasangan (paired sample t-test).

Uji beda paired sample t-test dalam penelitian ini digunakan untuk membandingkan rata-rata dari dua kelompok yaitu kelompok pertama adalah kinerja keuangan UMKM yang diproksikan dengan jumlah aset, omset penjualan dan laba bersih sebelum mendapatkan pembiayaan syariah dan kelompok kedua adalah kinerja keuangan UMKM sesudah mendapatkan pembiayaan syariah pada tahun 2013. Dalam hal ini, variabel kinerja UMKM sesudah mendapatkan pembiayaan syariah (X2) akan dilihat dan dibandingkan apakah terdapat perbedaan dengan variabel kinerja UMKM sebelum mendapatkan pembiayaan syariah (X1).

Kriteria yang digunakan dalam penelitian ini untuk pengujian hipotesis adalah sebagai berikut (Ghozali, 2016):

- Jika $p$ value lebih besar dari $\alpha=$ $5 \%$, maka $\mathrm{H}_{0}$ diterima dan $\mathrm{Ha}$ ditolak

- jika $p$ value lebih kecil atau sama dengan $\alpha=5 \%$, maka $\mathrm{H}_{0}$ ditolak dan Ha diterima

\section{HASIL DAN PEMBAHASAN}

Hasil Uji Hipotesis Pertama

Hipotesis pertama dalam
penelitian ini adalah terdapat
perkembangan jumlah aset UMKM
sesudah mendapatkan pembiayaan
syariah.

Kriteria pengujian yang digunakan dalam penelitian adalah:

a. Jika signifikansi (2-tailed) $>0,05$ maka $\mathrm{H}_{0}$ diterima dan $\mathrm{H}_{\mathrm{a}}$ ditolak

b. Jika signifikansi (2-tailed) $\leq 0,05$ maka $\mathrm{H}_{0}$ ditolak dan $\mathrm{H}_{\mathrm{a}}$ diterima
Dari hasil pengujian, output SPSS menunjukkan bahwa rata-rata jumlah aset UMKM sebelum mendapatkan pembiayaan syariah sebesar Rp 57.847.760,60 dan standar deviasi Rp 23.664.607,72. Sedangkan rata-rata jumlah aset UMKM sesudah mendapatkan pembiayaan syariah sebesar Rp 73.166.618,53 dan standar deviasi $\mathrm{Rp}$ 30.109.653,78. Hal ini menunjukkan bahwa terdapat kenaikan rata-rata jumlah aset UMKM sesudah mendapatkan pembiayaan syariah.

Output SPSS juga menunjukkan bahwa korelasi antara aset UMKM sebelum mendapatkan pembiayaan syariah dan aset UMKM sesudah mendapatkan pembiayaan syariah adalah sebesar 0,994 dengan signifikansi sebesar 0 . Hal ini mengindikasikan bahwa korelasi antara rata-rata jumlah aset UMKM sebelum mendapatkan pembiayaan syariah dengan rata-rata jumlah aset UMKM sesudah mendapatkan pembiayaan syariah adalah kuat dan signifikan. Pada output SPSS dapat dilihat bahwa nilai signifikansi (2-tailed) sebesar 0. Nilai ini akan dibandingkan dengan $\alpha=5 \%$ atau 0,05 (tingkat kepercayaan 95\%). Karena nilai signifikansi $(0)<\alpha(0,05)$ maka dapat disimpulkan bahwa $\mathrm{H}_{0}$ ditolak dan $\mathrm{H}_{\mathrm{a}}$ diterima, artinya rata-rata jumlah aset nasabah UMKM sebelum dan sesudah mendapatkan pembiayaan syariah adalah berbeda. Dengan demikian dapat dinyatakan bahwa terdapat perkembangan jumlah aset UMKM di Kabupaten Cirebon sesudah mendapatkan pembiayaan syariah. Dengan kata lain, pembiayaan yang diberikan oleh Bank Syariah Mandiri Cabang Cirebon kepada nasabah UMKM efektif meningkatkan jumlah aset UMKM di Kabupaten Cirebon. 


\section{Hasil Uji Hipotesis Ke Dua}

Hipotesis ke dua dalam penelitian ini adalah terdapat perkembangan jumlah omset penjualan UMKM sesudah mendapatkan pembiayaan syariah.

Kriteria pengujian yang digunakan dalam penelitian adalah:

a. Jika signifikansi (2-tailed) > 0,05 maka $\mathrm{H}_{0}$ diterima dan $\mathrm{H}_{\mathrm{a}}$ ditolak

b. Jika signifikansi (2-tailed) $\leq 0,05$ maka $\mathrm{H}_{0}$ ditolak dan $\mathrm{H}_{\mathrm{a}}$ diterima

Berdasarkan output SPSS dapat dilihat bahwa rata-rata jumlah omset penjualan UMKM sebelum mendapatkan pembiayaan syariah sebesar Rp 728.329.267,38 dan standar deviasi Rp 294.141.343,41. Sedangkan rata-rata jumlah omset penjualan UMKM sesudah mendapatkan pembiayaan syariah sebesar $\mathrm{Rp}$ 812.962.427,48 dan standar deviasi $\mathrm{Rp}$ 334.551.709,22. Hal ini menunjukkan bahwa terdapat kenaikan rata-rata jumlah omset penjualan UMKM sesudah mendapatkan pembiayaan syariah. Korelasi antara omset penjualan UMKM sebelum mendapatkan pembiayaan syariah dan omset penjualan UMKM sesudah mendapatkan pembiayaan syariah adalah sebesar 0,997 dengan signifikansi sebesar 0 . Hal ini mengindikasikan bahwa korelasi antara rata-rata jumlah omset penjualan UMKM sebelum mendapatkan pembiayaan syariah dengan rata-rata jumlah omset penjualan UMKM sesudah mendapatkan pembiayaan syariah adalah kuat dan signifikan. Nilai signifikansi (2-tailed) sebesar 0. Nilai ini akan dibandingkan dengan $\alpha=5 \%$ atau 0,05 (tingkat kepercayaan 95\%). Karena nilai signifikansi $(0)<\alpha(0,05)$ maka dapat disimpulkan bahwa $\mathrm{H}_{0}$ ditolak dan $\mathrm{H}_{\mathrm{a}}$ diterima, artinya rata-rata jumlah omset penjualan UMKM sebelum dan sesudah mendapatkan pembiayaan syariah adalah berbeda. Dengan demikian dapat dinyatakan bahwa terdapat perkembangan jumlah omset penjualan UMKM di Kabupaten Cirebon sesudah mendapatkan pembiayaan syariah. Dengan kata lain, pembiayaan yang diberikan oleh Bank Syariah Mandiri Cabang Cirebon efektif meningkatkan jumlah omset penjualan UMKM di Kabupaten Cirebon.

\section{Hasil Uji Hipotesis Ke Tiga}

Hipotesis ke tiga dalam penelitian ini adalah terdapat perkembangan jumlah laba bersih UMKM sesudah mendapatkan pembiayaan syariah.

Kriteria pengujian yang digunakan dalam penelitian adalah:

a. Jika signifikansi (2-tailed) > 0,05 maka $\mathrm{H}_{0}$ diterima dan $\mathrm{H}_{\mathrm{a}}$ ditolak

b. Jika signifikansi (2-tailed) $\leq 0,05$ maka $\mathrm{H}_{0}$ ditolak dan $\mathrm{H}_{\mathrm{a}}$ diterima

Output SPSS menunjukkan bahwa rata-rata jumlah laba bersih UMKM sebelum mendapatkan pembiayaan syariah sebesar $\mathrm{Rp}$ 68.422.086,72 dan standar deviasi $\mathrm{Rp}$ 28.278.882,24. Sedangkan rata-rata jumlah laba bersih UMKM sesudah mendapatkan pembiayaan syariah sebesar Rp 76.360.631,50 dan standar deviasi Rp 32.195.399,23. Hal ini menunjukkan bahwa terdapat kenaikan rata-rata jumlah laba bersih UMKM sesudah mendapatkan pembiayaan syariah. Korelasi antara laba bersih UMKM sebelum mendapatkan pembiayaan syariah dan laba bersih UMKM sesudah mendapatkan pembiayaan syariah adalah sebesar 0,997 dengan signifikansi sebesar 0. Hal ini mengindikasikan bahwa korelasi antara rata-rata jumlah laba bersih UMKM sebelum dan sesudah mendapatkan pembiayaan syariah 
adalah kuat dan signifikan. nilai signifikansi (2-tailed) sebesar 0. Nilai ini akan dibandingkan dengan $\alpha=5 \%$ atau 0,05 (tingkat kepercayaan 95\%). Karena nilai signifikansi $(0)<\alpha(0,05)$ maka dapat disimpulkan bahwa $\mathrm{H}_{0}$ ditolak dan $\mathrm{H}_{\mathrm{a}}$ diterima, artinya rata-rata jumlah laba bersih UMKM sebelum dan sesudah mendapatkan pembiayaan syariah adalah berbeda. Dengan demikian dapat dinyatakan bahwa terdapat perkembangan jumlah laba bersih UMKM di Kabupaten Cirebon sesudah mendapatkan pembiayaan syariah. Dengan kata lain, pembiayaan yang diberikan oleh Bank Syariah Mandiri Cabang Cirebon efektif meningkatkan jumlah laba bersih UMKM di Kabupaten Cirebon.

\section{PEMBAHASAN}

Hasil pengujian dalam penelitian ini menerima hipotesis pertama bahwa terdapat peningkatan jumlah aset UMKM sesudah mendapatkan pembiayaan syariah. Berdasarkan hasil perhitungan nilai rata-rata (mean), kinerja keuangan UMKM yang diukur dengan jumlah aset mengalami peningkatan sesudah mendapatkan fasilitas pembiayaan dari Bank Syariah Mandiri Cabang Cirebon. Ini berarti bahwa pembiayaan yang diperoleh dari bank salah satunya diinvestasikan oleh UMKM Kabupaten Cirebon dalam bentuk aset. Investasi dalam bentuk aset ini diharapkan dapat meningkatkan produksi maupun penjualan. Penggunaan aset secara efektif dalam kegiatan produksi maupun penjualan menyebabkan UMKM kian berkembang usahanya sehingga mampu meningkatkan keuntungan juga. Hasil penelitian ini sejalan dengan penelitian yang dilakukan oleh Nofianti (2013) yang menganalisis dampak pembiayaan UMKM oleh BPR di Bali terhadap kinerja UMKM. Nofianti (2013) menemukan bahwa jumlah aset UMKM mengalami peningkatan sesudah memperoleh pembiayaan dari BPR. Nurfriani, Paramu dan Utami (2014) dalam penelitiannya menganalisis kinerja UMKM di Kabupaten Jember. Mereka menemukan bahwa jumlah aset UMKM yang memperoleh pinjaman lebih besar dibandingkan jumlah aset UMKM yang tidak memperoleh pinjaman.

Hasil pengujian dalam penelitian ini juga menerima hipotesis ke dua bahwa terdapat peningkatan jumlah omset penjualan UMKM sesudah mendapatkan pembiayaan syariah. Berdasarkan hasil perhitungan nilai rata-rata (mean), kinerja keuangan UMKM yang diukur dengan jumlah omset penjualan mengalami peningkatan sesudah mendapatkan fasilitas pembiayaan dari Bank Syariah Mandiri Cabang Cirebon. Hal ini mengindikasikan bahwa UMKM di Kabupaten Cirebon mampu mencapai volume atau penjualan yang lebih tinggi dengan memanfaatkan pembiayaan dari bank syariah. Fasilitas pembiayaan yang diperoleh dari Bank Syariah Mandiri Cabang Cirebon benar-benar dijadikan tambahan modal oleh UMKM, dikelola dengan baik, seefektif dan seefisien mungkin untuk meningkatkan produksi ataupun penjualan. Hasil penelitian ini sejalan dengan penelitian yang dilakukan oleh Marcellina dan Setiawan (2012) dimana dalam penelitiannya mereka menemukan bahwa terjadi peningkatan omset penjualan pedagang dan pengusaha mikro di Kota Semarang sesudah mendapatkan kredit mikro dari Koperasi Enkas Mikro. Penelitian lainnya yang juga sejalan dengan hasil penelitian ini yaitu penelitian yang dilakukan oleh Nofianti (2013). Nofianti (2013) menemukan bahwa omset penjualan UMKM mengalami peningkatan sesudah memperoleh 
pembiayaan dari BPR. Rahayu, Purnamawati dan Maharani (2014) dalam penelitiannya juga menemukan bahwa omset penjualan UMKM mengalami peningkatan hingga dua kali lipat sesudah mendapatkan pembiayaan Al'Bai Bitsaman Ajil dari BMT Maslahah Sidogiri. Demikian halnya Saparingga, Nurhasanah dan Nurhayati (2015) yang juga membuktikan bahwa terjadi perkembangan UMKM dalam hal peningkatan omset penjualan sesudah mendapatkan pembiayaan mikro dari BRI Syariah.

Hasil pengujian juga menerima hipotesis ke tiga bahwa terjadi peningkatan laba bersih UMKM sesudah mendapatkan pembiayaan syariah. UMKM yang mendapatkan pembiayaan dari Bank Syariah Mandiri Cabang Cirebon memiliki kewajiban kepada bank untuk mengembalikan pinjaman berikut bagi hasilnya. Kewajiban inilah yang mendorong dan menjadi motivasi UMKM untuk menghasilkan laba yang lebih besar. Hasil penelitian ini sejalan dengan penelitian Marcellina dan Setiawan (2012) yang menganalisis dampak kredit mikro terhadap perkembangan usaha mikro di Kota Semarang. Hasil penelitian menunjukkan bahwa terjadi peningkatan keuntungan pedagang dan pengusaha mikro sesudah mendapatkan kredit mikro dari Koperasi Enkas Mikro. Hal serupa juga ditemukan oleh Rahayu dkk (2014) dan Saparingga dkk (2015) yang berhasil membuktikan bahwa terjadi peningkatan laba bersih UMKM sesudah mendapatkan pembiayaan.

\section{KESIMPULAN}

1. Terdapat peningkatan jumlah aset UMKM di Kabupaten Cirebon sesudah mendapatkan pembiayaan dari Bank Syariah Mandiri Cabang Cirebon.
2. Terdapat peningkatan omset penjualan UMKM sesudah mendapatkan pembiayaan dari Bank Syariah Mandiri Cabang Cirebon.

3. Terdapat peningkatan laba bersih UMKM sesudah mendapatkan pembiayaan dari Bank Syariah Mandiri Cabang Cirebon.

\section{IMPLIKASI}

Pembiayaan yang disalurkan oleh Bank Syariah Mandiri Cabang Cirebon terbukti efektif dalam meningkatkan kinerja keuangan UMKM di Kabupaten Cirebon. Hal tersebut ditunjukkan dengan adanya peningkatan aset, omset penjualan dan laba bersih UMKM sesudah mendapatkan pembiayaan syariah. Untuk itu diharapkan agar bank syariah senantiasa meningkatkan porsi pembiayaan kepada UMKM karena terbukti memberikan dampak positif bagi peningkatan kinerja mereka. Hendaknya bank syariah khususnya Bank Syariah Mandiri Cabang Cirebon tidak terlalu menerapkan prosedur yang sulit dan berbelit-belit kepada UMKM dan memberikan kemudahankemudahan bagi mereka untuk mengakses pembiayaan. Selain dukungan dari perbankan, pemerintah juga hendaknya senantiasa meningkatkan dukungan dan keberpihakannya kepada UMKM secara terus-menerus dan menyeluruh. Pemerintah bisa menunjukkan dukungannya kepada UMKM dalam bentuk kebijakan-kebijakan yang berpihak kepada UMKM, baik menyangkut permodalan, fasilitas, sarana dan prasarana, pendampingan dan pelatihan kepada UMKM yang memang menunjang peningkatan sektor tersebut. Dukungan perbankan khususnya bank syariah maupun dukungan pemerintah kepada UMKM sudah tentu menjadi modal utama bagi 
UMKM untuk terus menjalankan fungsi dan peranannya sebagai katup pengaman perekonomian bangsa.

\section{Keterbatasan Penelitian}

1. Penelitian ini hanya dilakukan pada satu bank syariah saja, yaitu hanya pada Bank Syariah Mandiri Cabang Cirebon sehingga ada kemungkinan hasilnya tidak dapat digeneralisasikan untuk objek yang berbeda.

2. Penelitian ini hanya menganalisis kinerja keuangan UMKM sebelum dan sesudah mendapatkan pembiayaan syariah menggunakan jumlah aset, omset penjualan dan laba bersih sebagai indikatornya. Untuk itu perlu dilakukan penambahan indikator kinerja UMKM yang lainnya, misalnya permodalan, risiko, inovasi dan lain sebagainya untuk melihat sejauh mana keefektifan penyaluran pembiayaan oleh bank syariah khususnya Bank Syariah Mandiri Cabang Cirebon terhadap pengembangan UMKM di Kabupaten Cirebon.

3. Periode penelitian kurang luas karena hanya satu tahun sehingga kurang efektif sehingga ada kemungkinan hasil penelitian tidak dapat digeneralisasikan untuk kondisi yang berbeda.

\section{Saran}

Mengingat bahwa penelitian ini memiliki keterbatasan maka rekomendasi yang disarankan untuk penelitian mendatang diantaranya:

1. Untuk penelitian sejenis yang akan datang perlu dilakukan perluasan objek penelitian, tidak hanya dilakukan pada salah satu bank syariah saja, sehingga hasil penelitian dapat lebih menggambarkan kondisi yang sebenarnya mengenai kinerja keuangan UMKM sebelum dan sesudah mendapatkan pembiayaan dari bank syariah.

2. Perlu dilakukan penambahan indikator kinerja UMKM yang lainnya, misalnya permodalan, risiko, inovasi dan lain sebagainya untuk melihat sejauh mana keefektifan penyaluran pembiayaan oleh bank syariah khususnya Bank Syariah Mandiri Cabang Cirebon terhadap pengembangan UMKM di Kabupaten Cirebon.

3. Untuk penelitian sejenis yang akan datang dapat lebih memperluas periode penelitian agar pengamatan terhadap kinerja keuangan UMKM yang diproksikan oleh aset, omset penjualan dan laba usaha dapat lebih dibandingkan antara sebelum dan sesudah mendapatkan pembiayaan dari bank syariah.

\section{Daftar Pustaka}

Bank Indonesia. 2015. Undang-Undang Republik Indonesia Nomor 21 Tahun 2008 Tentang Perbankan Syariah. Diakses melalui www.bi.go.id pada tanggal 9 Februari 2015.

Ghozali, Imam. 2016. Aplikasi Analisis Multivariate dengan program IBM SPSS 23. Badan Penerbit Universitas Diponegoro, Semarang.

Indriantoro, Nur dan Supomo, Bambang. 2009. Metodologi Penelitian Bisnis Untuk Akuntansi dan Manajemen. BPFE UGM, Yogyakarta.

Jubaedah, S dan Destiana, R. 2015. Impilkasi Pembiayaan Syariah Terhadap Perkembangan Usaha Mikro Kecil dan Menengah (UMKM) di Kabupaten Cirebon. Laporan Penelitian, Unswagati Cirebon. 
Marcellina, A.L., Setiawan, A.H. 2012.

Analisis Dampak Kredit Mikro Terhadap Perkembangan Usaha Mikro di Kota Semarang (Studi Kasus: Nasabah Koperasi Enkas Mulia). Diponegoro Journals of Economics 1(2): 1-7.

Memba, S. F., Gakure, W. R., dan Karanja, K. 2012. Ventura Capital : Its Impact on Growth of Small and Medium Enterprise in Kenya.

Rahayu, S.P., Purnamawati, I., Maharani, B. 2014. Analisis Perkembangan UMKM Pada Pembiayaan Al-Bai' Bitsaman Ajil (BBA) Pada Usaha Produktif (Studi Kasus Pada UMKM Nasabah Dari BMT Maslahah Sidogiri Cabang Olean Situbondo). Artikel Ilmiah. Fakultas Ekonomi Universitas Jember.

Saparingga, W., Nurhasanah, N., Nurhayati, N. 2015. Analisis Perbandingan Tingkat Perkembangan Usaha Mikro Kecil dan Menengah Sebelum dan Sesudah Mendapatkan Fasilitas Pembiayaan Mikro (Studi Kasus di BRI Syariah KCP Kopo Bandung). Prosiding Keuangan dan Perbankan Syariah 1(2): 314321.
Rahmana, A. 2008. Kinerja keuangan UKM di Indonesia. Diakses melalui

https://infoukm.wordpress.com/20 08/08/11/kinerja keuangan-ukmdi-indonesia/ pada tanggal 26 Mei 2015.

Swastha, Basu. 2001. Manajemen penjualan. Edisi 3. BPFE UGM, Yogyakarta.

Widodo, Tri, et al. 2003. Dampak Pola Pembiayaan Usaha Skala Mikro Terhadap Kinerja Bank dan Nasabah (ULM PT Bank BNI Wilayah Jabotabek, Jawa Barat dan DI Yogyakarta). Kerjasama Pusat Studi Ekonomi \& Kebijakan Publik Universitas Gajah Mada dan Tim Penelitian \& Pengembangan Biro Kredit Bank Indonesia. 